\title{
RISING STATELESSNESS DUE TO DISAPPEARING ISLAND STATES: DOES THE CURRENT STATUS OF INTERNATIONAL LAW OFFER SUFFICIENT PROTECTION?
}

\author{
MARIJA DOBRIĆ*
}

Scientific prognoses have shown that by the year 2100, several low-lying island states such as Tuvalu and Kiribati will disappear due to rising sea levels. The submergence of whole territories will have consequences including the displacement of a huge number of islanders. In that context, the question of how to protect their human rights in their future host states is of great importance. In fact, their human rights protection will most likely prove even more difficult if disappearing island states are considered to have lost statehood. Without the nationality of any state, those displaced islanders will be stateless under international law. In this article, the author assesses whether displaced island populations are sufficiently protected by existing international law norms or whether the international community is called upon to create new rules addressing these future challenges.

\section{TABLE OF CONTENTS}

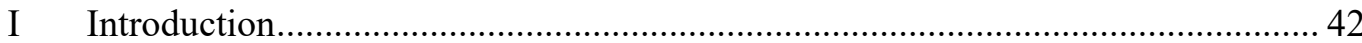

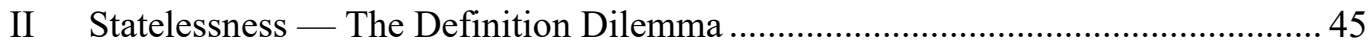

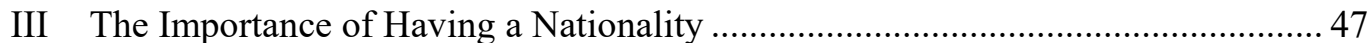

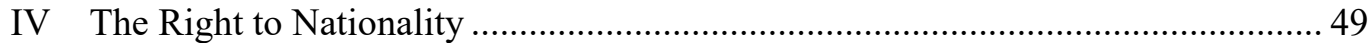

V Loss of Nationality on the Example of Disappearing Island States.........................52

A Continuing Statehood of Disappearing Island States?............................... 53

B De Lege Lata Protection Possibilities for an Externally Displaced

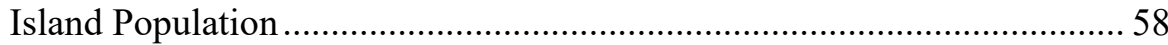

$1 \quad$ The 1954 and 1961 Statelessness Conventions ................................. 58

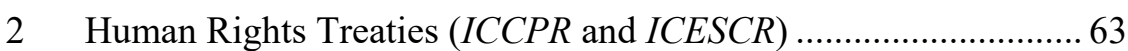

3 The Refugee Convention ................................................................. 64

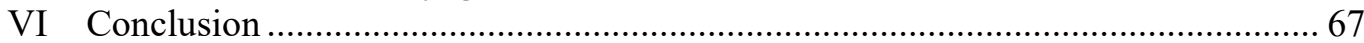

\section{INTRODUCTION}

As of today, many millions of people around the world are stateless. ${ }^{1}$ Despite that large number, the protection regimes under international law that are currently in place fail to safeguard their human rights adequately. The most recent flight of the stateless Rohingya people from the territory of Myanmar and its wide coverage in

\footnotetext{
* Marija Dobrić was a Researcher and Lecturer at the Section for International Law and International Human Rights Law at the Bundeswehr University Munich before taking up her current position as a Judicial Clerk at the Higher Regional Court of Vienna.

1 United Nations High Commissioner for Refugees, 'Statelessness around the World', $<$ http://www.unhcr.org/statelessness-around-the-world.html $>$.
} 
the media illustrate this dilemma. ${ }^{2}$ The lack of protection might be partially explained by the limited ratification of the two United Nations 'Conventions on Statelessness' - the 1954 Convention Relating to the Status of Stateless Persons ('1954 Convention') and the 1961 Convention on the Reduction of Statelessness ('1961 Convention'). ${ }^{3}$ This is particularly the case with regard to states, which would most likely serve as host states to fleeing stateless persons in the future. To date, only 91 states have ratified the 1954 Convention and 73 states are party to the 1961 Convention. ${ }^{4}$ Additionally, statelessness is still a comparatively underrepresented area in international legal scholarship, especially when comparing it to intertwined fields such as refugee law or international human rights law in general. ${ }^{5}$ Yet, it is a person's nationality 6 - at least from a state's perspective $^{7}$ — which matters a great deal when claiming a 'human' right vis-ávis a state. The lack of nationality not only limits which fundamental rights are granted by states on the domestic level but also the enjoyment of international human rights. Hence, should a state refuse to grant citizenship to persons permanently residing in its territory, it thus hinders these persons to effectively enjoy a wide range of civil, political and social rights. ${ }^{8}$ On the international level, the United Nations High Commissioner for Refugees ('UNHCR') set the goal in its Global Action Plan to End Statelessness 2014-24. ${ }^{9}$ At first glance and given the upcoming challenges in international law, however, that seems rather illusionary.

2 Approximately one year ago, the clearance operations against the Rohingya people started in Myanmar. Almost one million Rohingya refugees live now in the world's biggest refugee camps in Bangladesh. As their return to Myanmar is still considered too dangerous, their future remains unknown. Michael Safi, "We Cannot Go Back": Grim Future Facing Rohingya One Year after Attacks' The Guardian (London, 25 August 2018) $<$ https://www.theguardian.com/global-development/2018/aug/24/rohingya-one-year-afterattacks>.

3 Convention Relating to the Status of Stateless Persons, opened for signature 28 September 1954, 360 UNTS 117 (entered into force 6 June 1960) ('1954 Convention'); Convention on the Reduction of Statelessness, opened for signature 30 August 1961, 989 UNTS 185 (entered into force 13 December 1975) ('1961 Convention').

4 See United Nations Treaty Collections, 'Multilateral Treaties Deposited with the Secretary General - Chapter V: Refugees and Stateless Persons' $<$ https://treaties.un.org/Pages/Treaties.aspx?id=5\&subid=A\&clang=_en $>$ ('Refugees and Stateless Persons Page').

5 Alice Edwards and Laura van Waas, 'Introduction' in Alice Edwards and Laura van Waas (eds), Nationality and Statelessness under International Law (Cambridge University Press 2014) 1. See also Will Hanley, 'Statelessness: An Invisible Theme in the History of International Law' (2014) 25(1) European Journal of International Law 321, 321-27.

6 As there is no 'fundamental' difference between nationality and citizenship, the terms will be used synonymously for the purpose of this paper.

7 Please note that there is a difference between fundamental human rights, which are granted by, for example, a state's constitution and international human rights, applicable to everyone by virtue of being human. See Part III for more details.

8 David Weissbrodt and Clay Collins, 'The Human Rights of Stateless Persons' (2006) 28(1) Human Rights Quarterly 245, 248: '[M] any states only allow their own nationals to exercise full civil, political, economic, and social rights within their territories'. See also Part III.

9 United Nations High Commissioner for Refugees, Global Action Plan to End Statelessness 2014-24 (Action Plan, 2014) <https://www.unhcr.org/enau/protection/statelessness/54621bf49/global-action-plan-end-statelessness-2014-

2024.html $>$. See also United Nations High Commissioner for Refugees, 'Stateless People', $<$ http://www.unhcr.org/stateless-people.html $>$. See generally Matthew Seet, 'The Origins of UNHCR's Global Mandate on Statelessness' (2016) 28(1) International Journal on Refugee Law 7. 
More specifically, the international legal framework is faced with the challenge of addressing several effects of climate change, one of the most drastic being the case of disappearing island states. ${ }^{10}$ By all estimates, the territory of several lowlying island states - such as the Maldives or Tuvalu - will become submerged due to sea level rise in the foreseeable future. ${ }^{11}$ Hence, the submergence of whole nations might result in rising numbers of stateless people by the end of the $21^{\text {st }}$ century. The issue of disappearing island states has also not evaded the attention of the International Law Association ('ILA'), a private organisation, which has as its objective 'the study, clarification and development of international law'. ${ }^{12}$ It has established the ILA Committee on International Law and Sea Level Rise ('ILA Sea Level Rise Committee'), which aimed to consider in its final report in 2018 inter alia whether questions such as the continuing statehood of disappearing island states as well as its 'human dimension' 'need to be addressed by treaty law or whether customary international law and "softer" methods of norm creation will be sufficiently flexible to address these challenges'. ${ }^{13}$

This contribution will focus on a selected number of issues concerning the current status of international law with regard to disappearing island states. The core question of this paper is whether the de lege lata regime is sufficient to counter the challenge of effective human rights protection of displaced island populations. ${ }^{14}$ Disappearing island states are without precedent in international law. For the purpose of this article, it will thus be assumed that the whole territory of island states will be submerged under the sea. The article will, in Part II, start by illustrating several pertinent problems with regard to the definition of statelessness. The importance of nationality for the enjoyment of human rights especially with regard to their effective enforcement - will be underlined in Part III. Part IV will analyse whether there exists a so-called right to nationality in international law, which could serve as a possible solution to the problem of statelessness. Part V is divided into two parts: Part V(A) will address the question whether island states may still be considered 'states' once they are submerged. The answer to this question is particularly important in order to determine whether displaced islanders may enjoy protection under the Conventions on Statelessness. Part V(B) will conclude by demonstrating that existing international law instruments might not be effective enough to protect the human rights of displaced populations of disappearing island states.

10 See generally Leonard A Nurse et al, 'Small islands' in V R Barros et al (eds), Climate Change 2014: Impacts, Adaptation, and Vulnerability - Part B: Regional Aspects (Contribution of Working Group II to the Fifth Assessment Report of the Intergovernmental Panel on Climate Change 2014) 1613-54. Note one of the most recent scientific articles on the issue of accelerated sea level rise, Robert S Nerem et al 'Climate-Change - Driven Accelerated SeaLevel Rise Detected in the Altimeter Era' (2018) 115(9) PNAS 2022, 2022-25.

11 Other low-lying island states that will most probably disappear are Tuvalu, Kiribati, Marshall Islands, Nauru etc. See Jenny Grote Stoutenburg, Disappearing Island States in International Law (Brill Nijhoff 2015) 40; Alister Doyle, 'Rising Seas Scariest Climate Impact: Nauru's Moses' (Reuters 26 April 2011) <https://www.reuters.com/article/us-climate-nauruidUSTRE73P6TU20110426>.

12 International Law Association, 'About Us' <http://www.ila-hq.org/index.php/aboutus/aboutus $2>$.

13 International Law Association Committee on International Law and Sea Level Rise, The Johannesburg Conference: Final Report (Report, 2016) 11.

14 While the commonly used Latin expression de lege lata means 'of the current/existing law', de lege ferenda expresses 'new law' or 'what the law should be'. Both expressions are of particular importance to this contribution, since the current law will be assessed and measured against the need of a possible 'future law' for the protection of displaced islanders due to disappearing island states. 


\section{StATELESSNESS - The Definition DilemMA}

At the outset of the discussion, it is of primary importance to settle the definition of statelessness. It will be shown that the well-known problem of distinguishing between de jure and de facto stateless persons is still not resolved. Subsequently, the legal differences between falling in the category of stateless persons and the 'mere' reliance on international human rights regimes will be examined in more depth in Part V(B).

The 1954 Convention contains a legal definition of who may be considered stateless. ${ }^{15}$ According to art 1, a stateless person is 'a person who is not considered a national by any State under the operation of its laws'. ${ }^{16}$ There are different ways in which someone might become stateless within the meaning of art 1 . A person might not have acquired the nationality of one state automatically at their birth and was not awarded one afterwards. Alternatively, a person might have lost their nationality, eg the state revoked their citizenship at a later stage in life (this could be due to memberships in subversive groups, serving in the armed forces of a foreign state etc). ${ }^{17}$ In principle, states have sovereignty over the act of granting citizenship to a person. ${ }^{18}$ International law poses few restrictions (eg the prohibition of discrimination) in this regard. ${ }^{19}$ Although not having absolute discretion, it thus predominantly depends on the will of states if they recognise someone as a national. ${ }^{20}$ With regard to granting citizenship at birth, national legislation will generally either require a person to have a link through jus soli and/or jus sanguinis to the state. ${ }^{21}$ Different to the granting of citizenship, protection standards with regard to the deprivation of nationality limit the

15 For instance, the 1961 Convention (n 3) does not itself contain a definition on statelessness. It is however recognised that the art 11954 Convention definition is applicable. Carol Batchelor, 'The 1954 Convention Relating to the Status of Stateless Persons: Implementation within the European Union Member States and Recommendations for Harmonization' (2005) 22(2) Refuge 31, 53. See also Laura van Waas, 'The UN Statelessness Conventions' in: Alice Edwards and Laura van Waas (eds), Nationality and Statelessness under International Law (Cambridge University Press 2014) 64, 72.

16 According to the International Law Commission this definition has become part of customary international law, see International Law Commission, Report of the International Law Commission, UN GAOR, $58^{\text {th }}$ sess, Supp No 10, UN Doc A/61/10 (1 May 2006) 48-49 ('ILC Articles on Diplomatic Protection'); Alice Edwards, 'The Meaning of Nationality in International Law in an Era of Human Rights' in Alice Edwards and Laura van Waas (eds), Nationality and Statelessness under International Law (2014) 11, 27.

17 Eric Fripp, Nationality and Statelessness in the International Law of the Refugee Status (Hart 2016) 95 .

18 See also art 1 of the 1930 Convention on Certain Questions Relating to the Conflict of Nationality Laws, opened for signature 13 April 1930, 179 LNTS 89, entered into force 1 July 1937 ('1930 Hague Convention'), which explicitly states that 'it is for each State to determine under its own law who are its nationals'.

19 States also have to comply with applicable human rights obligations with regard to the granting of nationality: United Nations Human Rights Council, Human Rights and Arbitrary Deprivation of Nationality: Report of the Secretary-General, $13^{\text {th }}$ sess, Agenda Item 3, UN Doc A/HRC/13/34 (14 December 2009) [20]. See also Walter Kälin and Jörg Künzli, The Law of International Human Rights Protection (Oxford University Press 2010) 500.

20 Walter Kälin and Jörg Künzli (n 19) 500.

21 Jus soli means to acquire nationality when being born on the territory of a state. Jus sanguinis confers nationality via descent. For a detailed analysis on the different modes of nationality acquisition (the jus solis and jus sanguinis principle etc): Eric Fripp (n 17) 25-30. 
sovereignty of states more strictly and are included in numerous international human rights treaties. ${ }^{22}$ Thus, several treaties prohibit the revocation of nationality if the person concerned would become stateless as a result. ${ }^{23}$

As illustrated above, the statelessness definition contained in art 1 of the 1954 Convention only refers to so-called de jure stateless persons. However, scholars have debated if the definition of a 'stateless person' should be understood as also including circumstances of de facto statelessness. ${ }^{24}$ According to the 1949 UN's A Study on Statelessness, such de facto stateless persons are persons who, 'having left the country of which they were nationals, no longer enjoy the protection and assistance of their national authorities' ${ }^{25}$ Although they remain nationals of a state, their legal bond to that state is in effect meaningless, as they are not able to enjoy the protection or benefits usually contingent on citizenship. ${ }^{26}$ In essence, their status amounts to a situation of statelessness - only that they are not 'stateless' by definition.

Consequently, as de facto stateless persons do not fall under the legal term of statelessness, they are not protected under the Conventions on Statelessness. As a result, the distinction between those two categories - de jure and de facto statelessness - exemplifies a gap in their legal protection. ${ }^{27}$

This legal distinction seems difficult to justify in light of the factual similarity of de jure and de facto stateless persons. Therefore, many calls have been made to also include de facto statelessness in the definition of art 1 of the 1954 Convention. ${ }^{28}$ The Final Act of the United Nations Conference of Plenipotentiaries on the Status of Refugees and Stateless Persons ('The Final Act of the 1954 Convention') supports the view that de facto statelessness is to be treated the same as de jure statelessness. ${ }^{29}$ The Final Act of the 1954 Convention recommends that:

[E]ach Contracting State, when it recognizes as valid the reasons for which a person has renounced the protection of the State of which he is a national, consider sympathetically the possibility of according to that person the treatment which the Convention accords to stateless persons. ${ }^{30}$

However, that recommendation is of a non-binding nature. ${ }^{31}$ The same applies to the Final Act to United Nations Conference on the Reduction or Elimination of

22 Michelle Foster and Hélène Lambert, 'Statelessness as a Human Rights Issue: A Concept Whose Time has Come’ (2016) 28(4) International Journal of Refugee Law 564, 577.

23 ibid

24 Weissbrodt and Collins (n 8) 251.

25 United Nations Ad Hoc Committee on Refugees and Stateless Persons, A Study on Statelessness, UN Doc E/1112 and Add.1 (1 August 1949) Introduction III.

26 There is also a possibility that a person cannot prove or verify their nationality, which makes it practically useless: Weissbrodt and Collins (n 8) 263-64.

27 ibid 251.

28 See eg ibid.

29 Final Act of the United Nations Conference of Plenipotentiaries on the Status of Refugees and Stateless Persons, opened for signature 14 December 1950, 360 UNTS 117 (entered into force 28 July 1951) ('Final Act of the 1954 Convention'). See also Jane McAdam, Climate Change, Forced Migration, and International Law (Oxford University Press 2012) 140-41.

30 Final Act of the 1954 Convention (n 29) art 3. With regard to the drafting history of the 1954 Convention (n 3), see Nehemiah Robinson, Convention Relating to the Status of Stateless Persons: Its History and Interpretation (Commentary Institute of Jewish Affairs, 1955) ('Statelessness Convention Commentary'). This commentary was reprinted by the Division of International Protection of the United Nations High Commissioner for Refugees in 1997.

31 McAdam, Climate Change, Forced Migration (n 29) 140-41. 
Statelessness ('The Final Act of the 1961 Convention'), which provides that 'persons who are stateless de facto should as far as possible be treated as stateless de jure to enable them to acquire effective nationality'. ${ }^{32}$ Thus, it is at state discretion to follow the recommendations made by the Final Acts to the Conventions on Statelessness. ${ }^{33}$

Nonetheless, Part V will show the practical importance of closing this gap in legal protection in the example of disappearing island states. For the purposes of this article it is, however, first necessary to explore the relevance of having a nationality in general. Subsequently it will be argued that nationality is essential for the effective enjoyment of human rights.

\section{The IMPORTANCE OF HAVING A NATIONALITY}

Statelessness and nationality are necessarily interlinked, as statelessness results from the fact that a person does not have the nationality of any state. However, not having a nationality has many detrimental consequences. The International Court of Justice ('ICJ') prominently held in its Nottebohm Case (Liechtenstien $v$ Guatemala) ('Nottebohm Case') that

nationality is a legal bond having as its basis a social fact of attachment, a genuine connection of existence, interests and sentiments, together with the existence of reciprocal rights and duties. ${ }^{34}$

Accordingly, states grant a range of rights only to their nationals. ${ }^{35}$ Most importantly, these guarantees include political participation rights such as the right to vote, rights to residence and free movement, consular assistance, or social benefits such as health care, social assistance or family benefits. ${ }^{36}$ Frequently, the right to education and employment is also linked to the nationality of a person, thus often driving stateless people into poverty. ${ }^{37}$ Rights are usually limited to nationals, as such, the right to nationality has been frequently called 'the right to have rights'. ${ }^{38}$ This applies both domestically as well as internationally: without nationality, persons will not enjoy certain fundamental rights under domestic constitutional law; likewise the enforcement of human rights on the international

32 Final Act of the United Nations Conference on the Elimination or Reduction of Future Statelessness, opened for signature 4 December 1954, 989 UNTS 250 (entered into force 30 August 1961) 279 ('Final Act of the 1961 Convention'); See also McAdam, Climate Change, Forced Migration (n 29) 141.

33 See also van Waas, Nationality and Statelessness (n 15) 81: 'it remains to be seen whether states are willing to go beyond their present obligations and nevertheless extend international protection'. See also Final Act of the 1954 Convention (n 29); Final Act of the 1961 Convention (n 32); 1954 Convention (n 3); 1961 Convention (n 3).

34 Nottebohm Case (Liechtenstein v Guatemala) (Second Phase) (Judgment) [1955] ICJ Rep 4, 23 ('Nottebohm Case').

35 See, eg, Staatsgrundgesetz über die allgemeinen Rechte der Staatsbürger 1867 [Basic Law on the General Rights of Citizens 1867] (Austria) arts 2, 3, 6, 12; Grundgesetz für die Bundesrepublik Deutschland 1949 [Basic Law for the Federal Republic of Germany] (Germany) arts 8, 9, 11, which only offer protection to citizens.

36 Katja Swider, 'Why End statelessness' in Tendayi Bloom, Katherine Tonkiss and Phillip Cole (eds), Understanding Statelessness (Routlege 2017) 191, 192; Edwards (n 16) 12. See also Kristy A Belton, 'Statelessness and Economic and Social Rights' in Lanse Minkler (ed), The State of Economic and Social Human Rights (Cambridge University Press 2013) 221.

37 Cf Katja Göcke, 'Stateless Persons' in Rüdiger Wolfrum (ed), Max Planck Encyclopedia of Public International Law (Oxford University Press, 2012) vol 9, 551[3].

38 This phrase stems from philosopher and writer Hannah Arendt, who was stripped of her nationality by Nazi Germany. Weissbrodt and Collins (n 8) 248. 
level is severely curtailed. ${ }^{39}$ As a result, the sovereign right of states to grant citizenship comes into tension with the rights of individuals.

While stateless persons might not enjoy fundamental rights granted under a state's constitution because they lack citizenship, they may still enjoy human rights under international law. Since 1945, international law has increasingly granted rights to individuals - most importantly human rights - also heightening the importance of nationality on the international level. ${ }^{40}$ Accordingly, international human rights treaties - such as the International Covenant on Civil and Political Rights ('ICCPR') - generally oblige a state to protect persons who find themselves on its territory or jurisdiction. ${ }^{41}$ Stateless persons might therefore fall under the protection of such human rights treaties, if the pertinent violation occurs in the state's territory or under its jurisdiction. ${ }^{42}$ In that case, a state is under the obligation to protect the rights of stateless persons. However, the enforcement of such human rights obligations via states proves to be the actual obstacle to the enjoyment of human rights. The difficulties pertaining to enforcement will be illustrated below.

The enforcement of human rights on the international level is generally entrusted to the home state, which might exercise diplomatic protection on behalf of its nationals against violations of their rights by other states. ${ }^{43}$ This traditional concept of diplomatic protection is also espoused by the International Law Commission ('ILC') in its Articles on Diplomatic Protection and consequently requires the bond of nationality between the protecting state and the person. ${ }^{44}$ However, the ILC Articles on Diplomatic Protection also provide exceptions regarding refugees and stateless persons. According to art 8(1) of the ILC Articles on Diplomatic Protection '[a] State may exercise diplomatic protection in respect of a stateless person who, at the date of injury and at the date of the official presentation of the claim, is lawfully and habitually resident in that State'. ${ }^{45}$ While the efforts to propose new rules for stateless people de lege ferenda are laudable, the ILC itself noted that art 8 is still 'an exercise in progressive development of the law' ${ }^{46}$ and thus cannot be considered to reflect customary international law. ${ }^{47}$ Consequently, international law does not yet foresee the possibility for states to exercise diplomatic protection on behalf of stateless persons.

39 See also Belton (n 36) 223.

40 The protection of international human rights has drastically increased post-Second World War. See also Edwards (n 16) 24.

41 International Covenant on Civil and Political Rights, opened for signature 16 December 1966, 999 UNTS 171 (entered in force 23 March 1976) art 2(1) ('ICCPR').

42 Cf Legal Consequences of the Construction of a Wall in the Occupied Palestinian Territory (Advisory Opinion) [2004] ICJ Rep 136, [107-11]; Human Rights Committee, Views: Communication No 52/1979, $13^{\text {th }}$ sess, UN Doc CCPR/C/13/D/52/1979 (29 July 1981) [12.1].

43 ILC Articles on Diplomatic Protection UN Doc A/61/10 (n 16) 24. See also Ahmadou Sadio Diallo (Guinea v DRC) (Preliminary Objections) [2007] ICJ Rep 582, 599 [39], where the International Court of Justice emphasised the customary nature of the ILC Articles on Diplomatic Protection art 1.

44 See also Panevezys-Saldutiskis Railway (Judgment) [1939] PCIJ (ser A/B) No. 76, 16, with reference to the requirement of 'the bond of nationality between the State and the individual which alone confers upon the State the right of diplomatic protection'.

45 ILC Articles on Diplomatic Protection UN Doc A/61/10 (n 16) 47.

46 ibid 48.

47 ibid. The ILC also cited the case of $R$ (Al Rawi and Others) $v$ Secretary of State for Foreign Affairs and Another [2006] EWHC 972, in which the England and Wales Court of Appeal held that art 8 is 'not yet part of international law'. 
This discussion notwithstanding, states may still attempt to enforce erga omnes (partes) norms with regard to stateless persons. ${ }^{48}$ Erga omnes obligations are a concern of all states. As such, they allow states to bring a claim before a court in absence of a direct injury. ${ }^{49}$ Consequently, every state would have standing in front of a court if an erga omnes obligation has been violated, even in respect of a non-national. However, the erga omnes character has only been confirmed by the $I C J$ in the context of the most important human rights violations such as slavery and racial discrimination, whereas human rights treaties on the universal level, such as the ICCPR and the International Covenant on Economic, Social and Cultural Rights ('ICESCR') 'do not confer on states the capacity to protect the victims ... irrespective of their nationality'. 50

On the international level, human rights treaty bodies may be empowered to consider complaints or communications by individuals themselves. ${ }^{51}$ Such individual complaint mechanisms are, for example, foreseen in the Optional Protocol to the International Covenant on Civil and Political Rights or the Optional Protocol to the International Convention on the Elimination of All Forms of Racial Discrimination itself. ${ }^{52}$ In those cases, stateless persons without the nationality of any state could also petition violations of their human rights. However, in this case, enforcement of their human rights is rather unsatisfactory. ${ }^{53}$ Although stateless persons are able to present their claims before human rights treaty bodies, their decisions (eg the decisions of the Human Rights Committee) are not legally binding and only serve as suggestions to state parties. ${ }^{54}$

To conclude, individuals will generally have to rely on the protection of states via diplomatic protection to enjoy their human rights effectively. However, this is not a possible pathway for stateless persons.

\section{The Right to NATIONALITY}

In Part III, the importance of having a nationality for the effective enjoyment of human rights was assessed. In an attempt to address the problem of ineffective human rights protection, many scholars have argued for an obligation of states to

48 The Latin expression erga omnes (partes) means 'towards all ([treaty] parties)'.

49 Subject to diplomatic protection, a state generally only suffers injury if its nationals are harmed by another state. See also Barcelona Traction, Light and Power Company, Ltd (Belgium v Spain) (Judgment) [1970] ICJ Rep 3, [33]. See Part III above.

50 ibid [33]-[34], [91]. See also Malcolm N Shaw, International Law (Cambridge University Press 2017) 92-3; ICCPR (n 41); International Covenant on Economic, Social and Cultural Rights, opened for signature 16 December 1966, 993 UNTS 3 (entered into force 3 January 1976) ('ICESCR')

51 See generally, Dinah Shelton, 'Human Rights, Individual Communications/Complaints' in Rüdiger Wolfrum (ed), Max Planck Encyclopedia of Public International Law (Oxford University Press, 2012) vol 9, 1086-97.

52 Optional Protocol to the International Covenant on Civil and Political Rights, opened for signature 16 December 1966, 999 UNTS 171 (entered into force 3 March 1976); Optional Protocol to the International Convention on the Elimination of All Forms of Discrimination against Women, opened for signature 6 October 1999, 2131 UNTS 83 (entered into force 22 December 2000).

53 See eg Göcke (n 37) [20].

54 Belton (n 36) 237. For more details see Part V(B). 
confer nationality to an otherwise stateless person. ${ }^{55}$ For instance, art 1(1) of the 1961 Convention foresees an obligation to grant nationality - not with regard to every stateless person but - to persons born in the territory of a state if it would otherwise render them statelessness. ${ }^{56}$ However, this is again a treaty obligation, only binding for ratifying states of the 1961 Statelessness Convention. It is questionable, however, whether there exists a so-called 'human right to nationality'. ${ }^{57}$ Article 15(1) of the Universal Declaration of Human Rights (' $U D H R$ ') stipulates prominently that everyone has the right to a nationality. ${ }^{58}$ It also states that no one should be arbitrarily deprived of their nationality. ${ }^{59}$ Additionally, the innovative case law by the Inter-American Court of Human Rights with regard to art 20 American Convention on Human Rights ('ACHR'), which grants to every person a right to nationality, might suggest that there could be such a right on the universal level. ${ }^{60}$ Moreover, art 24(3) ICCPR, which incorporates the right of every child to acquire a nationality should also be mentioned here. 61

While the incorporation of a right to nationality in the UDHR demonstrates the international community's early awareness of the problem of statelessness, art 15 does not create a legal obligation for states to grant citizenship to a person, as the $U D H R$ is a non-binding instrument. ${ }^{62}$ Thus, reference to art 15 in the context of a legal obligation on states to confer citizenship to stateless persons might only serve as a starting point in order to evaluate whether there is a customary international norm. Moreover, neither does art 1(1) of the 1961 Convention nor art 24(3) ICCPR recognise a general right to nationality, as they confer such right only to children

55 Cf Edwards (n 16), 29-30. See generally United Nations Human Rights Council, Human Rights and Arbitrary Deprivation of Nationality: Report of the Secretary-General, $13^{\text {th }}$ sess, Agenda Item 3, UN Doc A/HRC/13/34 (14 December 2009) for more details on the right to nationality.

56 Luca Brücken and René de Groot, 'Deprivation of Nationality Under Article 8(3) of the 1961 Convention on the Reduction of Statelessness' (2018) 25(1) Maastricht Journal of European and Comparative Law 38, 40-41. See also Foster and Lambert (n 22) 567, 572.

57 Such a right of customary nature would bind states regardless of whether they have given their formal consent or have participated in the formation of the customary rule.

58 Universal Declaration of Human Rights, GA Res 217A (III), UN GAOR, UN Doc A/810 (10 December 1948).

59 ibid art 15(2).

60 American Convention on Human Rights, opened for signature 22 November 1969, 1144 UNTS 123 (entered into force 18 July 1978) art 20 ('ACHR'):

1. Every person has the right to a nationality.

2. Every person has the right to the nationality of the state in whose territory he was born if he does not have the right to any other nationality.

3. No one shall be arbitrarily deprived of his nationality or of the right to change it. Yean and Bosico v Dominican Republic (Preliminary Objections) (Inter-American Court of Human Rights, Series C No 1308 September 2005) ('Yean and Bosico v Dominican Republic').

61 ICCPR art 24(3). See also United Nations Human Rights Council, Human Rights and Arbitrary Deprivation of Nationality: Report of the Secretary-General, $13^{\text {th }}$ sess, Agenda Item 3, UN Doc A/HRC/13/34 (14 December 2009) [3] for a complete list of norms incorporating a right to nationality, including European Convention on Nationality, opened for signature 6 November 1997, ETS 166 (entered into force 01 March 2000) art 4 ('European Convention on Nationality'); emphasis should also be put on International Convention on the Elimination of All Forms of Racial Discrimination, opened for signature 21 December 1965, 660 UNTS 196 (entered into force 4 January 1969) art 5(d)(iii) ('CERD'), which requires equality before the law for everyone also with regard to the enjoyment of the right to nationality. Göcke (n 37) [10]; McAdam, Climate Change, Forced Migration (n 29) 139. 
born on the territory of a state. ${ }^{63}$ Therefore, when speaking of a so-called human right to nationality, scholarly debate should accurately distinguish between existing treaty provisions conferring a right to nationality on everyone (eg art 20 $A C H R)^{64}$ or only to children born on the territory of the host state (eg art 24(3) $I C C P R)$. While many instruments incorporate the right of children to acquire a nationality and the obligation not to render them stateless has indeed most likely become part of customary international law, it is difficult to find a 'general' right to nationality on the universal level. ${ }^{65}$

Based on the findings of the Nottebohm Case before the ICJ, scholars have nonetheless tried to argue innovatively for a right to nationality - applicable to everyone - primarily in the case of state succession. ${ }^{66}$ They referred to the socalled principle of effective nationality to propose that states might have a positive obligation to grant nationality to individuals if they have a 'genuine and effective' link to a state. ${ }^{67}$ Conversely, Guy S Goodwin-Gill merely proposed relying on the principle of effective nationality that, if a person has 'a social fact of attachment, a genuine connection of existence, interests and sentiments' with regard to a particular state, it might be bound by incidental obligations such as that of nonexpulsion or readmission. ${ }^{68}$ However, the reliance on the Nottebohm Case as support for an emerging right to nationality seems far-fetched at best. The Nottebohm Case was merely concerned with the question whether Liechtenstein was allowed to exercise diplomatic protection on behalf of its naturalised citizen Friedrich Nottebohm in respect of a claim against Guatemala. ${ }^{69}$ The ICJ held that since Nottebohm had no real and effective link to Liechtenstein, the question has to be answered in the negative. Besides the 'traditional' requirement of nationality, the Court also asked for the 'individual's genuine connection with the State' for the purpose of diplomatic protection. ${ }^{70}$ Consequently, it is difficult to use the Nottebohm Case as reference to establish 'a right to nationality'. ${ }^{71}$ However, the criterion of 'genuine or effective link' has already been used in regional instruments in the context of state succession. ${ }^{72}$

63 Foster and Lambert (n 22) 567.

64 Oliver Dörr, 'Nationality' in Rüdiger Wolfrum (ed), Max Planck Encyclopedia of Public International Law (Oxford University Press, 2012) vol 9496 [7].

65 Ineta Ziemele, 'State Succession and Issues of Nationality' in Alice Edwards and Laura van Waas (eds), Nationality and Statelessness under International Law (Cambridge University Press 2014) 243. Laura van Waas also speaks of the 'widespread recognition of a child's right to a nationality': van Waas (n 15) 84.

66 Nottebohm Case (n 34); See, eg, Foster and Lambert (n 22) 574, with reference to scholar Guy S Goodwin-Gill. See also, Jeffrey L Blackman, 'State Successions and Statelessness: The Emerging Right to an Effective Nationality under International Law' (1998) 19(4) Michigan Journal of International Law 1141, 1163: 'Nevertheless, the trend in international law, at least in the context of state succession, is moving in the direction of imposing positive legal obligations on states deriving from the principle of effective nationality enunciated in Nottebohm'.

67 Belton (n 36) 227.

68 Foster and Lambert (n 22) 574.

69 Nottebohm Case (n 34).

70 ibid, 23.

71 Cf Foster and Lambert (n 22) 574, with regard to the propositions made by Goodwin-Gill: 'He suggested, innovatively, that the criteria set out by the International Court of Justice in the Nottebohm Case to assess an individual's genuine connection with a State in the context of diplomatic protection may have relevance beyond this limited context'.

72 European Convention on Nationality (n 61). 
More specifically, there are two European instruments, which incorporate an obligation for ratifying states to grant their nationality to persons who would become stateless as a result of a state succession. ${ }^{73}$ In general, the right to nationality in those instruments functions more broadly as it not only applies to children but to all persons that at the time of the succession had the nationality of the predecessor state and where state succession would otherwise render them stateless. ${ }^{74}$ In 1999, the ILC adopted the Articles on Nationality of Natural Persons in Relation to Succession of States ('Articles on Nationality'), which also set out rules for the attribution of nationality in the context of state succession. ${ }^{75}$ However, those Articles on Nationality are not of a binding nature. ${ }^{76}$ Also in the case of state succession, scholar Francesco Costamagna writes that

the main concern of these documents is not to reassert the existence of a universal right to have a nationality, but simply to avoid that individuals might end up losing their nationality because of a change of sovereignty. ${ }^{77}$

To conclude, a more in-depth analysis on a so-called human right to nationality seems redundant since it is not considered to have acquired customary nature (yet). ${ }^{78}$

People without the nationality of any state in the world might enjoy protection under the 1954 Convention and the 1961 Convention. Especially with regard to disappearing island states, it is important to determine if displaced island populations would fall under the protection regime of the Conventions on Statelessness. The next Part will therefore analyse whether the population of disappearing island states would be considered as stateless under art 1 of the 1954 Convention.

\section{LOSS OF NATIONALITY ON THE EXAMPLE OF DisAPPEARING ISLAND STATES}

In Part II, the possibility of losing citizenship through state action was already touched upon. Such state action is usually called 'denationalisation' or 'withdrawal of citizenship'. However, the threat of losing a once possessed nationality does not solely lie in the sphere of a state, eg their nationality laws and corresponding government measures. Thus, statelessness may not only occur through arbitrary deprivation of nationality. ${ }^{79}$ Looking ahead, it is already possible to identify instances where a state would not deprive its citizens of citizenship voluntarily. Scientific prognoses on climate change show that several low-lying island states - such as the Maldives or the smaller Kiribati and Tuvalu islands -

73 ibid; Council of Europe Convention on the Avoidance of Statelessness in Relation to State Succession, opened for signature 19 May 2006, ETS 200 (entered into force 1 May 2009) ('Convention on the Avoidance of Statelessness in Relation to State Succession').

74 See, eg, Convention on the Avoidance of Statelessness in Relation to State Succession (n 73) art 2. Note, however, that according to art 5, some connection to the territory of the new state will be required to obtain citizenship.

75 International Law Commission, Report on its work of its fifty-first session, UN GAOR, $54^{\text {th }}$ sess, Supp No 10, UN Doc A/54/10 (3 September 1999).

76 Dörr (n 64) [9].

77 Francesco Costamagna, 'Statelessness in the Context of State Succession - An Appraisal under International Law' in Serena Forlati and Alessandra Annoni (eds), The Changing Role of Nationality in International Law (Routledge 2013) 37, 42.

78 Dörr (n 64) [9]; Edwards (n 16) 24. See also Blackman (n 66) 1176; McAdam, Climate Change, Forced Migration (n 29) 139; Belton (n 36) 227.

79 Cf Foster and Lambert (n 22) 567. 
will physically disappear by 2100 due to unavoidable sea level rise. ${ }^{80}$ In scholarly debate, there has already been discussion on whether the population of such states would lose its nationality if territory permanently disappears. ${ }^{81}$ If an island state should extinguish legally, the populations' citizenship to that state would also cease to exist, as the essential attachment to a state will be lacking. ${ }^{82}$ Accordingly, if there exists no state who grants citizenship to a person, it must follow that this person is stateless. ${ }^{83}$ The imminent global challenge of sea level rise could therefore lead to massive deprivations of citizenships and thus induce a global rise in statelessness in the future. It goes without saying that this would be detrimental to the vision of the UNHCR to end statelessness by $2024 .{ }^{84}$

This ultimately leads to the question of how to treat the population of a sinking island state - would they fall under the de jure definition of the 1954 Convention? Would it be desirable to have former islanders be considered as stateless? If not, how can they be protected by international law if they do not fall under the statelessness regime? In order to find an answer to these questions, one first needs to determine the general criteria of statehood and thus whether a sunken island state could still be considered to fulfil the requirements.

\section{A Continuing Statehood of Disappearing Island States?}

To begin with, there is no commonly agreed legal definition in international law on what constitutes a state. ${ }^{85}$ In order to evaluate the elements of statehood, scholars have however oriented themselves on a definition contained in the Convention on the Rights and Duties of States ('Montevideo Convention'), which reflects customary international law. ${ }^{86}$ According to art 1 of the Montevideo Convention, the criteria for statehood are ' $a$ ) a permanent population; b) a defined territory; c) an effective government; and d) the capacity to enter into relations with other states'. ${ }^{87}$ Additionally, criterion d) is also often replaced with the criterion of independence. ${ }^{88}$ Those criteria are not absolute and, when concerned with already existing states, not even the loss of all elements will immediately lead

80 See generally, Stoutenburg (n 11); See also McAdam, Climate Change, Forced Migration (n 29) 127; Nurse et al (n 10) 1613-54; Nerem et al (n 10) 2022-25.

81 This is different to other scenarios of state dissolution such as merger or succession, where state practice is available. There has not been an example of the entire loss of state territory so far. For more details on the extinction of states, see generally James Crawford, The Creation of States in International Law (Oxford University Press, $2^{\text {nd }}$ edn, 2006) 715-17.

82 See United Nations High Commissioner for Refugees, Climate Change and Statelessness: An Overview (Report, 15 May 2009) 1 ('Climate Change and Statelessness').

83 Heather Alexander and Jonathan Simon, 'Sinking into Statelessness' (2014) 19 Tilburg Law Review 20, 20-21. See also Paul Weis, Nationality and Statelessness in International Law (BRILL 1979) 136; McAdam, Climate Change, Forced Migration (n 29) 159.

84 Unfortunately, it must also be noted that the goal to prevent statelessness due to sea level rise was not adopted among the ten specific actions to end statelessness by United Nations High Commissioner for Refugees.

85 Crawford, The Creation of States in International Law (n 81) 45-95; McAdam, Climate Change, Forced Migration (n 29) 128; Climate Change and Statelessness (n 82) 1.

86 James Crawford, The Creation of States in International Law (n 81) 45-95; James Crawford, Brownlie's Principles of Public International Law (Oxford University Press, $8^{\text {th }}$ edn, 2012) 128.

87 Convention on the Rights and Duties of States, opened for signature 26 December 1933, 165 LNTS 19 (entered into force 26 December 1934); See Stoutenburg (n 11) 250; See also Shaw (n 50) 157.

88 Stoutenburg (n 11) 250. Cf Shaw (n 50) 160. 
to the extinction of the state. ${ }^{89}$ Considering a case where the whole territory of a state is submerged due to sea level rise, and thus the whole population and the government is displaced, the continuance of statehood in application of those criteria becomes highly questionable.

First, in our discussion on statehood we already start from the premise that a state's territory will vanish under rising sea levels. Thus, criteria b) - one of a defined territory - will undoubtedly be lacking. Although international law has not been faced with the total and irreversible loss of territory yet, some scholars have already considered it as a possible ground for the extinction of a state. ${ }^{90}$ While there is no number or percentage which must be met in order to satisfy the criterion of permanent population, ${ }^{91}$ statehood must at least require a small number of inhabitants. ${ }^{92}$ The described scenario of total disappearance with no possibility for inhabitants to live on the territory, however, would be of such gravity to reasonably negate the fulfilment of continuing statehood.

Regarding criteria c) it is important to highlight that international law presumes a state's continued existence despite a period without an effective government (eg failed states). ${ }^{93}$ There have been many instances in history where recognised governments were able to operate temporarily in exile on the territory of other states while suffering occupation. ${ }^{94}$ Governments in exile, however, may only establish its seat in a host state if they have the consent of the latter to exercise jurisdiction in the host state's territory. ${ }^{95}$ Additionally, it should be noted that examples of state practice so far pertain to circumstances in which regaining the lost government, territory and population appeared somewhat likely in a foreseeable future. ${ }^{96}$ That is not the case with regard to disappearing island states, due to the permanence of the status quo. After a nation is fully submerged, neither the government nor the displaced island population would be able to return to the sunken territory. Thus, where governments would be forced to perform permanently in exile due to the loss of territory, it seems at least questionable whether a state would host a foreign state under such circumstances, and thus in effect consent to the establishment of parallel state or state-like structures on its territory. Moreover, states are more inclined to permit governments on their territory if their performance in exile 'results from acts contrary to a peremptory

89 Crawford, Brownlie's Principles of Public International Law (n 86) 128; McAdam, Climate Change, Forced Migration (n 29) 128-29.

90 See, eg, Malcolm N Shaw (n 50) 164; Rosemary Rayfuse, 'International Law and Disappearing States — Maritime Zones and the Criteria for Statehood' (2011) 41(6) Environmental Policy and Law 281, 284.

91 There are some Pacific countries that have a large number or even half of their population living outside the territory: McAdam, Climate Change, Forced Migration (n 29) 131-32. This, however, does not lead to a state's extinction.

92 Crawford, Brownlie's Principles of Public International Law (n 86) 129. Then again, Shaw suggests that not even a nomadic population would satisfy the requirements of territorial integrity: Shaw (n 50) 158.

93 Crawford, The Creation of States in International Law (n 81) 34; Shaw (n 50) 160; McAdam, Climate Change, Forced Migration (n 29) 135.

94 Eg, governments in exile of German-occupied States during the Second World War. For more details in this regard, see generally Stefan Talmon, Recognition of Governments in International Law: With Particular Reference to Governments in Exile (Clarendon 1998).

95 ibid, 215-18. This flows from the principle of territorial sovereignty.

96 See also McAdam, Climate Change, Forced Migration (n 29) 136: 'The government in exile idea is premised on there still being an identifiable population over which the government has jurisdiction'. 
norm' ${ }^{97}$ Even if assuming that the government of a former island state would have the consent of a foreign state to function on its territory, its effectiveness would most probably eventually wane. ${ }^{98}$ The importance of sovereign territory for a government's ability to operate effectively should not be undervalued. ${ }^{99}$

Moreover, the aspect of independence should for the sake of completeness also be mentioned here. Apart from the criteria illustrated above, the capacity to enter into relations with other states and thus independence is also crucial to statehood. ${ }^{100}$ Independence in other words means inter alia that a state is unaffected by the 'factual dependence upon other states'. ${ }^{101}$ Hence, it may not be subject to the authority of a foreign state. ${ }^{102}$ While it will obviously depend on the host state whether governments in exile become subordinate, it seems rather reasonable to conclude that a state without territory will find itself more easily in dependency than other states. ${ }^{103}$ Thus, it only seems plausible to assume the end of statehood based on the criteria in the Montevideo Convention.

The ILA Executive Council established the ILA Sea Level Rise Committee in 2012 with the specific mandate 'to study the possible impacts of sea level rise and the implications under international law of the partial and complete inundation of state territory' and in this regard to 'to develop proposals for the progressive development of international law... including the impacts on statehood'. ${ }^{104}$ In its 2018 final report, the ILA Sea Level Rise Committee poses the question whether the problem of permanently uninhabitable state territory due to sea level rise would eg require international law to recognise a new category of subjects in international law, even if those entities lose their legal status as states. ${ }^{105}$ Although international law recognizes entities sui generis such as the Holy See or the Sovereign Order of Malta for historical reasons, it seems rather unlikely that submerged states will be

97 Crawford, Brownlie's Principles of Public International Law (n 86) 125; Rosemary Rayfuse and Emily Crawford, 'Climate Change, Sovereignty and Statehood', (Legal Studies Research Paper No 11/59, Sydney Law School, September 2011) 8:

If the government of a state has been forcibly displaced from its territory through belligerent occupation, the government in question is considered to remain the legitimate government and state... Under international law, such exile must be accepted by the international community; that is, there should be no general acknowledgement of a change of circumstances.

98 For instance, McAdam argues that a merger with the organs of the host state would ultimately lead to the extinction of the state if no other interests to uphold the continuance of statehood prevail: McAdam, Climate Change, Forced Migration (n 29) 137.

99 It is important to keep in mind that disappearing island states would not only lose territory but also their population. McAdam, Climate Change, Forced Migration (n 29) 160: '[A] substantial loss of population would start to erode the effectiveness of the State's government as its economic base declined'.

100 Shaw (n 50) 160.

101 ibid.

102 McAdam, Climate Change, Forced Migration (n 29) 133.

103 For more details on the independence criterion, see Crawford, The Creation of States in International Law (n 81) 62-89.

104 International Law Association, Committee on International Law and Sea Level Rise, Sydney Conference: Final Report (Report, 2018) 1 ('Sydney Conference Final Report').

105 ibid, 25. Regarding subjects of international law in general, see Crawford, Brownlie's Principles of Public International Law (n 86) 115-26. 
accepted to enter this category. ${ }^{106}$ After all, they have once possessed statehood. However, it will be interesting to see how the ILA Sea Level Rise Committee will approach this question in the future.

Some authors suggest that even if the whole territory of a state disappears, it is still possible that the international community would recognise the existence of its statehood. ${ }^{107}$ In general, international law has accepted the presumption of continuing statehood under certain circumstances. ${ }^{108}$ Thus, state practice so far suggests that the international community is willing to uphold recognition of states that no longer fulfil the criteria of statehood (eg failed states such as Somalia). ${ }^{109}$ Accordingly, in order to protect 'failed' states from unlawful invasion and annexation from other states, their continuing statehood will generally be presumed for a considerable amount of time. ${ }^{110}$ In contrast to situations of 'failed' states, the presumption of continuing statehood may also not be justified by preventing claims of neighbouring states to otherwise uncontrolled and stateless territory.

That distinction being made, scholars have specifically argued that the presumption of continuing statehood is not appropriate in the case of disappearing island states. ${ }^{111}$ They have also noted that the prevailing doctrine favours the declaratory theory, and recognition does not play a constitutive role in the determination of statehood. ${ }^{112}$ In that case, it would be absurd to recognise nonterritorial entities as states. ${ }^{113}$ Above all, there should be at least a minimum amount of territory left to recognise the continuance of statehood. ${ }^{114}$

It is important to keep in mind that the recognition of states remains a political act, and states will not base their decision to recognise a state strictly on the fulfilment of the statehood criteria. ${ }^{115}$ Consequently, it will be seen how far the

106 For instance, Taiwan is considered to have international legal identity, approximating to that of a state. However, such acknowledgment of a modified personality applies to 'case[s] of territory title to which is undetermined, which is inhabited and has an independent administration'. This does not apply to submerged island states: Crawford, Brownlie's Principles of Public International Law (n 86) 125. See also McAdam, Climate Change, Forced Migration (n 29) 159: suggesting that disappearing islands could at some point be regarded 'as having acquired a different kind of international personality, other than as a state'.

107 See, eg, Stoutenburg (n 11) 297; McAdam, Climate Change, Forced Migration (n 29) 140.

108 The requirements on fulfilling the statehood criteria are much more stringent in the context of the creation of new states. See also Crawford, The Creation of States in International Law (n 81) 34; See also Sydney Conference Final Report (n 104) 25.

109 Regarding Somalia, see Rayfuse and Crawford (n 97) 9

110 Crawford, The Creation of States in International Law (n 81) 63; McAdam, Climate Change, Forced Migration (n 29) 134. It is also noteworthy to mention International Law Commission, Report of the International Law Commission on the Work of Its Fifty-Third Session, UN GAOR, 56 ${ }^{\text {th }}$ sess, Supp No 10, UN Doc A/56/10 (10 August 2001) 286 art 41(2) ('ILC Articles on State Responsibility'): 'No State shall recognize as lawful a situation created by a serious breach within the meaning of article 40, nor render aid or assistance in maintaining that situation.' This article confers on states the obligation to refrain from recognising situations as lawful, which are created by jus cogens violations.

111 Alexander and Simon, 'Sinking into Statelessness' (n 83) 21.

112 ibid 24-25.

113 ibid.

114 Crawford, The Creation of States in International Law (n 81) 46.

115 Crawford, Brownlie's Principles of Public International Law (n 86) 147. See also Alexander and Simon, 'Sinking into Statelessness' (n 83) 25: 
political interest to uphold continuing statehood of disappearing island states will prevail over the lack of 'factual' statehood.

However, the question of how effectively a government acting from foreign territory is able to protect its citizens remains uncertain. Even if the international community could agree on the continuity of disappearing island states as legal entities, ${ }^{116}$ the externally displaced population would struggle to enjoy protection from a government forced to act in exile without territory; a situation, which according to UNHCR, would most likely amount to de facto statelessness. ${ }^{117}$

To conclude, the discussion regarding the continuance of statehood of disappearing island states is far from being uniformly acknowledged. Even the ILA Sea Level Rise Committee considered the question of continuing statehood of such 'great sensitivity' that it refrained from discussing it in more detail in its Sydney Conference: Final Report 2018.118 Instead, the ILA Sea Level Rise Committee evaluated that it would be useful to continue its work on the issue of statehood after the end of its current mandate. ${ }^{119}$ Unfortunately, it also did not touch upon the issues of nationality and statelessness in its report. ${ }^{120}$ The legal status of a submerged state and its population still remains unresolved. ${ }^{121}$

Note that we have not argued that in fact states will not continue to recognize submerged island nations as states. We have argued that the principle of presumption of continuity does not necessarily recommend that they do so, and we have argued that even if it did, it would not follow that these submerged entities really were states, any more than a boiled egg would be a state if recognized by the community of nations to be.

116 Stoutenburg (n 11) 405.

117 Climate Change and Statelessness (n 82) 2. See also Stoutenburg (n 11) 427.

118 Sydney Conference Final Report (n 104) 25-26.

119 ibid.

120 Ibid. However, the Committee's mandate also includes to

develop proposals for the progressive development of international law in relation to the possible loss of all or of parts of state territory and maritime zones due to sea level rise, including the impacts on statehood, nationality, and human rights. at 1.

121 See also Stoutenburg (n 11) 404. Some commentators have argued that former islanders will become de jure stateless even if the international community continues to recognise statehood of disappearing island states. They base their arguments on the premise that non-territorial states cannot comply with their duty to readmit nationals if other states request it; thus, they lose their ability to confer nationality under the operation of their law. This allegedly flows from the basic concept that a state cannot assume a duty (here: the international obligation to readmit nationals) if it cannot discharge it. For further details on this obligation, see also Kay Hailbronner, 'Readmission Agreements and the Obligation on States under Public International Law to Readmit their Own and Foreign Nationals' (1997) 57(1) Heidelberg Journal of International Law 1. Regarding that argument, see Heather Alexander and Jonathan Simon, 'No Port, No Passport: Why Submerged States Can Have No Nationals' (2017) 26(2) Washington International Law Journal 307. In the author's opinion, this seems a rather unconvincing argument. Under international law, the consequence of a state's 'factual' inability to comply with its obligation to readmit nationals cannot result in the loss of its sovereign right to confer nationality. In general, the violation of an international obligation towards another state must lead to state responsibility, if no circumstances precluding wrongfulness apply. Disappearing island states could, for example, try to argue force majeure (art 23 ILC Articles on State Responsibility (n 110)); that is the occurrence of an irresistible force, beyond the control of the state, making it materially impossible in the circumstances to readmit nationals to the state. The state as such, however, exists further and may, under the operation of its law, confer, regulate and withdraw nationality (in the limits of international law as elaborated further above). 


\section{Population}

Without any state practice, the scenario of disappearing island states raises many unsettled questions. At the core is the question of how to protect and guarantee human rights of externally displaced islanders. Rising sea levels will most likely jeopardise the protection of various human rights, including civil rights (eg the right to life), as well as many socio-economic rights such as the right to health, housing or the right to work. ${ }^{122}$ For the purpose of determining the various protection possibilities in the case of disappearing island states, different protection regimes - their applicability essentially depending on whether the population is considered stateless or not - will be illustrated below. It is important to highlight that the question of whether displaced islanders fall under the relevant protection regimes goes hand in hand with the question of whether their rights can be effectively enforced.

\section{The 1954 and 1961 Statelessness Conventions}

To begin with, it should be quickly re-emphasised that only a 'stateless person' may enjoy the protection of both Conventions on Statelessness. Whether the population of a disappearing state will be considered as de jure or de facto stateless, will ultimately depend on the will of the international community to continue to recognise islands as states once they are submerged. Only with regard to de jure stateless persons, ratifying states will have to fulfil the obligations set out in the Conventions on Statelessness. However, as illustrated above, states may still decide to follow the recommendations of the Final Acts to the Statelessness Conventions, which suggest to treat de facto stateless people as far as possible as de jure stateless people. ${ }^{123}$

If the population of former island states was to fall under the definition of stateless people, they would benefit from the protection regime provided under the 1954 Convention. ${ }^{124}$ This would entitle them to enjoy a range of human rights aimed at improving their status in the host state. ${ }^{125}$ For instance, the 1954 Convention incorporates a set of civil rights such as the freedom to practice religion (art 4), access to courts (art 16) and the right of association (art 15). ${ }^{126}$ Stateless persons also enjoy the right of freedom of movement, which is contained in art 26. ${ }^{127}$ Moreover, the 1954 Convention contains several economic and social rights, which are necessary for every person to live a minimally decent life. ${ }^{128}$ Of

122 McAdam, Climate Change, Forced Migration (n 29) 52.

123 Stoutenburg (n 11) 427-28; Final Act of the 1954 Convention (n 29); Final Act of the 1961 Convention (n 32). For more details, see Part II.

124 Note, however, that there are also scholars who apply such a narrow reading of art 1 of the 1954 Convention so as to consider de jure statelessness only in cases where states actually withdraw nationalities from people. This understanding would lead to the conclusion that although the island state ceases to exist, its population would not be considered to fall under the definition of art 1 of the 1954 Convention: Walter Kälin, 'Conceptualising ClimateInduced Displacement' in Jane McAdam (ed), Climate Change and Displacement. Multidisciplinary Perspectives (Bloomsbury 2010) 92; Stoutenburg (n 11) 404-5.

125 Foster and Lambert (n 22) 566.

126 van Waas (n 15) 73.

1271954 Convention (n 3) art 26.

128 Belton (n 36) 226, 228. 
those rights, arts 17-19 and 24 concerning 'the rights to work', art 21 with regard to 'the right to housing' and art 24, which incorporates 'the right to social security' should be highlighted. ${ }^{129}$ As can be seen, the 1954 Convention incorporates existing human rights standards, which can be found in various human rights treaties. ${ }^{130}$ Importantly, however, the 1954 Convention even goes beyond those standards. ${ }^{131}$ For instance, art 32 of the 1954 Convention includes an obligation to 'facilitate the assimilation and naturalization of stateless persons'. Thus, while the 1954 Convention does not confer an obligation on states to grant nationality to stateless persons, it does call on them to facilitate the naturalisation of stateless persons 'as quickly and easily as possible'. ${ }^{132}$ Moreover, arts 27 and 28 oblige states to issue travel documents to stateless persons within their territory. 133 Article 25 of the 1954 Convention foresees that stateless persons are afforded administrative assistance in cases where the assistance of authorities of a foreign country to whom the stateless person cannot have recourse would be required. Stateless persons greatly benefit from those provisions, which confer a legally binding obligation on host states to facilitate their naturalisation as well as to issue travel documents and to offer administrative assistance. ${ }^{134}$

In general - and different to the ICCPR or the ICESCR - the 1954 Convention sets out different standards of treatment, depending on the right in question. Some provisions require states to grant the same rights to stateless persons as are granted to their nationals, others accord to stateless persons the same level of treatment as granted to other non-nationals in the state. The 1954 Convention also grants several absolute rights to stateless persons regardless of whether they also exist for nationals. ${ }^{135}$ In general, however, the 1954 Convention shall accord to stateless persons the same treatment as is accorded to non-nationals in general (art 7(1)). Overall, the 1954 Convention is beneficial to stateless persons as it grants them a minimum standard of human rights as well as several guarantees that go beyond those rights incorporated in the ICCPR or ICESCR.

Importantly, several regional human rights courts have already stressed the relevance of 'legal identity' for the enjoyment of human rights in general. ${ }^{136}$ Many provisions in the 1954 Convention only grant protection to those stateless persons

129 Furthermore, the 1954 Convention (n 3) includes the right to access primary education and the right to be provided identification documents: Belton (n 36) 226.

$130 \operatorname{ICCPR}$ (n 41); ICESCR (n 50).

131 Stoutenburg (n 11) 427.

132 van Waas (n 15) 73.

133 Eg, Stoutenburg suggests that governments in exile would be still able to issue travel and identification documents: Stoutenburg (n 80) 427.

134 However, how those obligations - especially art 32 of the 1954 Convention (n 3) — can be exactly enforced against ratifying states is yet another question.

135 van Waas (n 15) 73.

136 Apleyeva and Dzhalagoniya v Russia (European Court of Human Rights, Chamber Application Nos 7549/09 and 33330/11, 12 June 2018); The Nubian Community in Kenya $v$ The Republic of Kenya (Merits) (African Commission on Human and People's Rights, Communication No 317/2006, 28 February 2015); IHRDA and OSJI (on behalf of children of Nubian descent in Kenya) v Kenya (African Committee of Experts on the Rights and Welfare of the Child Decision 002/COM/002/09, 22 March 2011); Marija Dobric and Philipp Janig, 'Stateless Persons and Social Rights' in Christina Binder et al (eds), Research Handbook on Social Rights (forthcoming). 
lawfully staying in the territory of the host state. ${ }^{137}$ Essentially, stateless persons unlawfully staying in the host state are only able to enjoy a limited number of rights under the 1954 Convention. As the legality of residence is subject to domestic legislation, states will in general enjoy wide discretion in determining the legal status of former islanders fleeing from disappearing island states. ${ }^{138}$ Thus, the requirement of lawful stay might be a pivotal barrier for stateless persons to enjoy the human rights stipulated therein; in particular as states will arguably not consider them refugees under the Convention Relating to the Status of Refugees ('1951 Refugee Convention'). ${ }^{139}$

Even if falling under the legal definition of a stateless person, the enjoyment of the rights stipulated in the 1954 Convention is not as simple as it may sound. Naturally, in order to benefit from the statelessness regime, a stateless person has to reside in a state party to the Conventions on Statelessness. As already mentioned above, ratification is poor, as is exemplified by the large number of neighbouring countries of endangered island states (which would most likely serve as refuge to former islanders) that have not ratified the Conventions on Statelessness. More precisely, of all those states that likely might serve as host states due to their geographical proximity to low-lying island states - eg India, Sri Lanka, Indonesia, the Philippines, Singapore, Malaysia, New Zealand, Papua New Guinea, the United States or Australia - only Australia and the Philippines have ratified the 1954 Convention. ${ }^{140}$

While the 1954 Convention could provide human rights protection, which goes even beyond basic human rights standards, most future host states in the case of disappearing island states have not yet ratified the Convention. Hence, stateless persons will not enjoy protection under the 1954 Convention unless the aforementioned states ratify it.

Additionally, the protection regime of the 1961 Convention should also be briefly mentioned here. In contrast to the 1954 Convention, its main focus is to prevent cases of statelessness from arising rather than the protection of basic human rights standards. ${ }^{141}$ As illustrated above, art 1(1) of the 1961 Convention does not confer a right to nationality to everyone but only to persons born on the territory of a state if they otherwise would be stateless. ${ }^{142}$ This means that the 1961 Convention only applies to children of displaced islanders born on the territory of the host state. ${ }^{143}$ Consequently, the original generation does not enjoy such a right under art 1(1).

Another core obligation in the 1961 Convention is art 8(1), which stipulates that states 'shall not deprive a person of its nationality if such deprivation would render him stateless'. While the 1961 Convention does not have a legal definition on the term deprivation, it is however regarded as the "withdrawal of citizenship

137 The following articles in the 1954 Convention (n 3) require lawful stay: art 15 (right of association), art 17 (wage-earning employment), art 18 (self-employment), art 19 (liberal professions), art 21 (housing), art 23 (public relief), art 24 (labour legislation and social security), art 26 (freedom of movement), art 28 (travel documents) and art 31 (expulsion).

138 For a detailed discussion on the importance of a legal status in the host state for the enjoyment of social rights: see Dobric and Janig (n 136).

139 Convention Relating to the Status of Refugees, opened for signature 28 July 2951, 189 UNTS 37 (entered into force 22 April 1954) ('1951 Refugee Convention'). See more on this issue further below.

140 'Refugees and Stateless Persons Page' (n 4). See Stoutenburg (n 11) 409.

141 Edwards (n 16) 28.

142 See Part IV for more details.

143 Stoutenburg (n 11) 428. 
that is initiated by state authorities'. ${ }^{144}$ As emphasised above, disappearing island states do not revoke citizenships of their populations voluntarily. The prohibition against arbitrary deprivation of nationality does also not apply to the case of disappearing states due to the aforementioned grounds. ${ }^{145}$

Therefore, the 1961 Convention will hardly provide redress to the problems created by virtue of the disappearance of island states. ${ }^{146}$

Moreover, unlike other international human rights treaties, the Conventions on Statelessness do not provide for any enforcement mechanisms, as elaborated above. However, the UN General Assembly awarded the UNHCR the mandate to work on four different issues concerning statelessness. ${ }^{147}$ This includes inter alia the task to advocate for the ratification of the Conventions on Statelessness as well the prevention of statelessness. ${ }^{148}$

In light of this, it is also important to highlight that some authors speak of an emerging trend towards the duty of states to prevent, or rather not to create, statelessness. ${ }^{149}$ The Explanatory Report of the European Convention on Nationality even states that the obligation to avoid statelessness has become part of customary international law. ${ }^{150}$

In essence, the scholarly debate on the duty to prevent is similar to that on the right to nationality. However, while various international and regional (human rights) treaties already include provisions with regard to a right to nationality, they do not explicitly refer to a duty to prevent statelessness. ${ }^{151}$ The content of such a duty in international law is not strictly defined yet. For instance, the Introductory Note of the UNHCR to the 1961 Convention itself states that in order to prevent statelessness '[s]tates may either grant nationality to children automatically at birth or subsequently upon application'. Apart from the conferral of nationality, which is inherent in the right to nationality, the duty to prevent also includes a prohibition on the withdrawal of nationality if such deprivation would render

144 Brücken and Groot (n 56) 40.

145 For further details on arbitrary deprivation of nationality, see Foster and Lambert (n 22) 578.

146 ibid 581. However, it should also be noted that the general effectiveness of art 8(1) is limited due to the possibility of states to retain the right to deprive citizens of their nationality by means of a declaration under art 8(3) at the time of ratification of the 1961 Convention (n 3); See generally, Brücken and Groot (n 56).

147 Seet (n 9) 8.

148 ibid 8, 20.

149 Such a duty to prevent statelessness upon states would be of customary nature. As such, it is relevant to determine uniform state practice as well as opinio juris.

150 European Convention on Nationality (n 61) [33]. Please also note the European Convention on Nationality explicitly provides in art 4(b) that statelessness shall be avoided. See generally Foster and Lambert (n 22) 578.

151 See 1930 Hague Convention (n 18) arts 14, 15; ICCPR (n 41) art 24; Convention on the Elimination of All Forms of Discrimination Against Women, opened for signature 18 December 1971, 1249 UNTS 1 (entered into force 3 September 1981) ('CEDAW') art 9; Convention on the Rights of the Child, opened for signature 20 November 1989, 1577 UNTS 3 (entered into force 2 September 1990) ('CRC') art 7-8; International Convention on the Protection of the Rights of All Migrant Workers and Members of their Families, opened for signature 18 December 1990, 2220 UNTS 3, (entered into force 1 July 2003) ('ICRMW') art 29; ACHR (n 60) art 20. See also Yean and Bosico v The Dominican Republic (n 60) [140][143], where the Inter-American Commission on Human Rights speaks of the 'obligation to prevent, avoid and reduce statelessness' by citing: 1961 Convention (n 3) art 1(1); ICRMW at art 29; $C R C$ at art 7(1); ICCPR at art 24(3). With regard to the gradual development of the 'duty to prevent', see Tang Lay Lee, 'Denationalization and Statelessness in the Modern World' (2006) 6 ISIL Year Book of International Humanitarian \& Refugee Law 19, 34-37. It must be noted that Tang Lay Lee explicitly refers to the 'duty to prevent statelessness' and not the right to nationality when citing the provisions above. 
persons stateless. ${ }^{152}$ It seems that the duty to prevent statelessness shall include all cases in which a person could become stateless; thus, it applies very broadly. Bearing that in mind, it is arguable that the duty to prevent statelessness is already partly implicit in the right to nationality (of children). ${ }^{153}$ More precisely, if states are bound by an obligation to confer nationality to children born on the territory of their state, states necessarily must also be bound by an obligation to not render them stateless and vice versa. ${ }^{154}$

However, it is unclear how future host states of fleeing islanders might be bound under a duty to prevent statelessness. ${ }^{155}$ There are several scholarly contributions, which have discussed a possible duty to prevent if statelessness arises from state succession. While there might be such a customary obligation in the context of state succession, ${ }^{156}$ it seems questionable how such a duty - if legally binding - would apply in the context of disappearing island states. ${ }^{157}$ Clearly, future host states to fleeing islanders are not successor states of submerged Pacific islands. As such, they do not have to assume the same responsibility as successors, which 'replace a predecessor state in the responsibility for the international relations of territory'. ${ }^{158}$ The link former nationals of the predecessor state have to the successor state is manifestly stronger than the one former islanders might have to their new state of residence. Under current customary international law, a duty to prevent statelessness might only be assumed with regard to stateless children, born on the territory of the host state.

To conclude, several problems with regard to the effective enjoyment of human rights under the Conventions on Statelessness have been analysed above. However, displaced islanders in the Asia-Pacific region will usually also enjoy protection under general human rights guarantees, which are applicable to all human beings.

152 Again, please note the Introductory Note of the United Nations High Commissioner for Refugees to the 1961 Convention (n 3):

The Convention further seeks to prevent statelessness later in life by prohibiting the withdrawal of citizenship from States' nationals - either through loss, renunciation, or deprivation of nationality — when doing so would result in statelessness.

153 As already elaborated above, there is no general right to nationality under customary international law. However, it was argued that there potentially exists such a right for stateless children. This discussion, however, leaves any applicable treaty provisions unaffected. For instance, under $A C H R$ (n 60) art 20, states are indeed bound by a general right to nationality.

154 See, eg, CRC (n 151) art 7(1), which provides, inter alia, such a right to nationality for children. Furthermore, art 7(2) stipulates that state parties to the $C R C$ shall ensure the implementation of the rights found in para 1 in particular where the child would otherwise be stateless. As such, art 7 could be understood as incorporating a duty to prevent statelessness.

155 Disappearing island states cannot be bound under the duty to prevent statelessness, as they are not withdrawing their citizenships.

156 However, even in the context of state succession, some scholars argue that it is difficult to identify a customary obligation to grant nationality to everyone. See Ziemele (n 65) 243. Dörr (n 64) [9].

157 Cf Blackman (n 66) 1176-83.

$158 \mathrm{Cf}$ Convention on the Avoidance of Statelessness in Relation to State Succession (n 73) art 1(a). 
There are several international human rights treaties that would provide protection to stateless persons, where they are applicable. ${ }^{160}$ The ICCPR and the ICESCR the most prominent human rights treaties on the universal level - incorporate a wide set of basic human rights, some of which have already been illustrated above in the context of the 1954 Convention. Substantively, the ICCPR grants civil and political rights, whereas the ICESCR incorporates economic, social and cultural rights. Out of all rights, art $24 I C C P R$ should be specifically mentioned here, as it provides for a right to nationality for every child. Article $24 I C C P R$, however, which accordingly only guarantees the right of children to acquire a nationality born in the territory of a state, will add little to help displaced islanders who will have to migrate to other states. In cases where their children are born stateless on the host state's territory, art 24(3) ICCPR might indeed prove valuable.

The ICCPR and the ICESCR are both widely ratified instruments, including in the Asia-Pacific region. ${ }^{161}$ While the 'advances of international human rights law which obligates all states to protect human rights regardless of the status of the holder' 162 should not be undermined, it is however always pertinent to question how human rights can be actually enforced vis-à-vis a state, in particular the host state. As eluded to above in Part III, the possibility of exercising diplomatic protection on behalf of stateless people as provided for in the ILC Articles on Diplomatic Protection has so far not been accepted by state practice. But even if that were the case, the ILC Articles on Diplomatic Protection themselves also grant that right only to the resident state which, arguably, will be the most likely to violate the displaced islander's human rights on its territory. Under these circumstances, the possibility of enforcement remains alarmingly limited. Even if states recognise continuing statehood and islanders do not lose their nationalities, it remains uncertain whether island states would be able to guarantee human rights effectively while having their governments act in exile on foreign territory.

Moreover, whether individuals may rely on treaty mechanisms in the context of their human rights, such as the Human Rights Committee, is contingent on acceptance by the respective state. This again is limited in the affected region, which would most probably serve as host states for displaced island populations. Thus, it must be noted that the status of ratification of several 'optional protocols',

159 Please note that the $C E R D$ (n 61) and the $C E D A W$ (n 151) will not be specifically mentioned under the human rights treaties section. They might also apply to stateless persons; however, their statelessness does not arise due to discriminatory state action or laws. However, both conventions may provide redress with regard to discriminatory treatments in future host states.

160 Not only the ICCPR (n 41) and ICESCR (n 50), but also the CERD (n 61), CEDAW (n 151) (as already mentioned above), the Convention against Torture and Other Cruel, Inhuman or Degrading Treatment or Punishment, opened for signature 10 December 1984, 1465 UNTS 85 (entered into force 26 June 1987) ('CAT'), the CRC (n 151); the ICRMW (n 151), the International Convention on the Protection of All Persons from Enforced Disappearance, opened for signature 20 December 2006, 2716 UNTS 3 (entered into force 23 December 2010) and the Convention on the Rights of Persons with Disabilities, opened for signature 13 December 2006, 2515 UNTS 3 (entered into force 03 May 2008) are international human rights instruments which, if applicable, might protect stateless persons from human rights violations in future host states.

161 See accordingly the status of ratification of the ICCPR (n 41) and the ICESCR (n 50) at the official website of Office of the High Commissioner for Human Rights, 'Status of Ratification' <http://indicators.ohchr.org/> ('Status of Ratification').

162 Amal de Chickera and Laura van Waas, 'Unpacking Statelessness' in Tendayi Bloom, Katherine Tonkiss and Phillip Cole (eds), Understanding Statelessness (Routledge 2017) 59. 
which would provide for the possibility of individual complaint mechanisms, is limited in the Asia-Pacific region. ${ }^{163}$

To sum up, while stateless persons will most certainly fall under the protection regimes of the ICCPR and the ICESCR as they are widely ratified and applicable to everyone, it remains questionable whether stateless persons might effectively enforce those human rights vis-à-vis their host states without the possibility of enjoying diplomatic protection.

The 1954 Convention is largely modelled on the 1951 Refugee Convention, 164 although in comparison to the Refugee Convention, it eg lacks a provision prohibiting refoulement as well as the penalisation of illegal entry. ${ }^{165}$

Stateless persons might fall under the international refugee protection regime, if certain circumstances are met. ${ }^{166}$ Article $1 \mathrm{~A}(2)$ deals first with persons with a nationality. After a semicolon, art $1 \mathrm{~A}(2)$ stipulates that a stateless person, as a person 'not having a nationality and being outside the country of his former habitual residence... is unable or, owing to such fear, is unwilling to return to it', is - if fulfilling these criteria — to be considered as falling under the refugee definition. In the context of disappearing island states, it must be mentioned that the question of whether 'climate refugees' can be considered as refugees at all under art $1 \mathrm{~A}(2)$ has already received wide attention in legal scholarship. ${ }^{167}$ In general, it is recognised that it will be difficult, if not impossible, to prove that natural disasters give rise to a 'well-founded fear' of persecution. ${ }^{168}$ While art $1 \mathrm{~A}(2)$ stipulates the requirement of a well-founded fear of persecution for nationals of a state, it subsequently merely states that a stateless person must be 'unable or, owing to such fear, unwilling to return' to its country of habitual residence. If considerable emphasis is put on the ordinary meaning of art $1 \mathrm{~A}(2)$, it

163 See 'Status of Ratification' (n 161). Please also note that the author will refrain from elaborating on protection mechanisms through regional human rights instruments, such as the American Convention on Human Rights or the European Convention on Human Rights, as they would not be applicable in the relevant region.

164 See Statelessness Convention Commentary (n 30) 1: '[I]n many instances the relevant articles of the Refugee Convention were taken over bodily by substituting the words "stateless person" for "refugee", See also Foster and Lambert (n 22) 566.

165 Foster and Lambert (n 22) 566.

1661951 Refugee Convention (n 139) art 1A(2).

167 ibid.

168 There are several problems to the application of art 1A(2) to ecological 'refugees', which cannot be dealt with in its entirety here. However, it should be stressed that persecution necessarily requires attribution of a violation of the person's human rights to a state. In the case of disappearing island states, it will be difficult to determine one single state actor as responsible for the vanishing of a state's territory (in the end, disappearing island states cannot be held responsible for rising sea levels on their own). The reasoning behind the Teitiota cases in New Zealand is similar: see Teitiota v The Chief Executive of the Ministry of Business Innovation and Employment [2013] NZHC 3125; Teitiota $v$ The Chief Executive of the Ministry of Business, Innovation and Employment [2014] NZCA 173 ('Teitiota $v$ The Chief Executive of the Ministry of Business, Innovation and Employment'); Jane McAdam, 'The Emerging New Zealand Jurisprudence on Climate Change, Disasters and Displacement' (2015) 3(1) Migration Studies 131, 133-34. See also Andreas Zimmermann and Claudia Mahler, 'Article 1 A, para. 2' in: Andreas Zimmermann (ed), The 1951 Convention Relating to the Status of Refugees and its 1967 Protocol: A Commentary (Oxford University Press, 2011) 281, 440 [572]; Jane McAdam, 'Climate Change Displacement and International Law', (Speech, Side Event to the High Commissioner's Dialogue on Protection Challenges, 8 December 2010) ('Climate Change Displacement and International Law'). 
is arguable that stateless persons might be considered as refugees if they merely prove to be 'unable to return' to their country of former habitual residence without being persecuted per se. ${ }^{169}$ Heather Alexander and Jonathan Simon have argued that such inability to return must be understood as 'irreparable, fundamental inability, rather than mere difficulty of complication with the paperwork'.170 However, many recognise that stateless persons shall not be treated any different to refugees (so-called 'single test' for refugee status). Although it is undeniable that the wording of art $1 \mathrm{~A}(2)$ seems ambiguous with regard to the requirement of persecution for persons lacking a nationality, it is thus generally accepted that both the unwillingness, as well as the inability to return to the country of former habitual residence, must be based on a well-founded fear of being persecuted on Convention grounds. ${ }^{171}$

To conclude, it would be unconvincing to argue that a stateless person fleeing due to disappearing island states would fall under the refugee definition in art $1 \mathrm{~A}(2)$, if no other circumstances which would give rise to 'well-founded fear', arose.

Again, it would be desirable to achieve some international consensus on this issue. Sweden and Finland explicitly recognise ecological migrants under certain, but strict, circumstances as 'persons otherwise in need of protection'. ${ }^{172}$ For instance, former islanders fleeing to Sweden might succeed in applying for protection on the grounds of 'a person otherwise in need of protection', if not already considered as refugees (nor persons requiring subsidiary protection). ${ }^{173}$

169 See generally Heather Alexander and Jonathan Simon, "Unable to Return" in the 1951 Refugee Convention: Stateless Refugees and Climate Change' (2014) 26(3) Florida Journal of International Law 531.

170 ibid 532-33: Alexander and Simon make a convincing point when arguing that where a strict test is applied to the inability to return, an application of refugee status without persecution is justifiable. In the author's opinion, however, the scholars neglect a discussion whether 'is unable or, owing to such fear, is unwilling to return to it' could by way of textual interpretation be read as requiring persecution for the inability and the unwillingness to return, respectively.

171 Zimmermann and Mahler (n 168) 463 [685]-[686]; Guy S Goodwin-Gill and Jane McAdam, The Refugee in International Law (Oxford University Press 2007) 69-70. See also Council Directive 2004/83/EC of 29 April 2004 on Minimum Standards for the Qualification and Status of Third Country Nationals or Stateless Persons as Refugees or as Persons who Otherwise Need International Protection and the Content of the Protection Granted [2004] OJ L 304/12, art 2(c).

172 See Aliens Act 2005 (Sweden) ch 4, s 2(a), which considers a 'person otherwise in need of protection' is someone who 'is an alien who in cases other than those referred to in Section 1 is outside the country of the alien's nationality, because he or she [... 3) is unable to return to the country of origin because of an environmental disaster'. See also Hélène Ragheboom, The International Legal Status and Protection of Environmentally-Displaced Persons: A European Perspective (Brill Nijhoff 2017) 352.

173 Ragheboom (n 172) 352; New Zealand and Australia have also not recognised 'ecological refugees' yet (for the relevant case law see n 168); McAdam, 'Emerging New Zealand Jurisprudence' (n 168). However, please note Teitiota v The Chief Executive of the Ministry of Business, Innovation and Employment (n 168), where the Supreme Court of New Zealand held at [13]:

That said, we note that both the Tribunal and the High Court, emphasised their decisions did not mean that environmental degradation resulting from climate change or other natural disasters could never create a pathway into the Refugee Convention or protected person jurisdiction. Our decision in this case should not be taken as ruling out that possibility in an appropriate case. 
While the Refugee Convention might not give stateless persons a right not to be returned to their home country, ${ }^{174}$ this might be the case under the nonrefoulement principle as a customary rule, which is also applicable to non-refugees (also known as 'complementary protection'). In general, the non-refoulement principle is violated where an individual is returned to serious harm. ${ }^{175}$

It appears dispensable to argue on the applicability of the non-refoulement principle when there is no territory to which host states could send former inhabitants back. Host states, however, might be restricted by the principle of nonrefoulement to return former islanders to territories that have not fully vanished, when sending them back might put their lives at risk due, for example, to scarce resources or a constant threat of sea floods. Especially considering that the European Court of Human Rights has recognised that where the applicant suffers from poverty or a lack of resources, housing/employment or medical care, it is 'only' in exceptional circumstances that the host state may not return the applicant. ${ }^{176}$ For instance, this is the case when a terminally ill person's life expectancy would be reduced significantly upon return. ${ }^{177}$ In essence, 'the humanitarian grounds against the removal' must be 'compelling'. ${ }^{178}$ Thus, the non-refoulement principle might become applicable in situations where former

174 This will essentially hinge on the question whether a former islander is consider a refugee under art $1 \mathrm{~A}(2)$ of the 1951 Refugee Convention. If considered falling under art 1A(2), a former islander may not be expelled under art 33(1), unless [2] is applicable (if the refugee is 'a danger to the security' or 'community of the country'). Please note that asylum-seekers may also enjoy protection under art 33. See also Goodwin-Gill and McAdam (n 170) 232-34.

175 See also the formulation in Soering $v$ United Kingdom (European Court of Human Rights, Chamber, Application No 14038/88, 7 July 1989) with regard to the non-refoulement principle implicit in art 3 of the Convention for the Protection of Human Rights and Fundamental Freedoms, opened for signature 4 November 1950, 213 UNTS 221 (entered into force 3 September 1953): "where substantial grounds have been shown for believing that the person, if extradited, faces a real risk of being subjected to torture or to inhuman or degrading treatment or punishment in the requesting state': at [91]. It must be noted that, theoretically, any human rights violation may give rise to the non-refoulement principle. However, where relative rights are concerned, states are permitted to balance their public interests against the interests of the individual concerned; McAdam, Climate Change, Forced Migration (n 29) 53, 81; Moreover, in the case of non-refoulement, the obligation to protect lies on the receiving country: see McAdam, 'Climate Change Displacement and International Law' (n 168).

176 In these cases, the feared harm was naturally occurring and the receiving state could not be held responsible for it. See especially the most cited case in this context, $D v$ United Kingdom (European Court of Human Rights, Grand Chamber, Application No 30240/96, 2 May 1997) where the Court held in [54]:

However, in the very exceptional circumstances of this case and given the compelling humanitarian considerations at stake, it must be concluded that the implementation of the decision to remove the applicant would be a violation of Article 3 .

The Court held in this case that the expulsion of a terminally ill man suffering from AIDS to St Kitts, where he could not receive adequate care for his illness, was in violation of art 3 . See also $N v$ United Kingdom (European Court of Human Rights, Grand Chamber, Application No 26565/05, 27 May 2008) ('N v United Kingdom') (no violation); Paposhvili v Belgium (European Court of Human Rights, Grand Chamber, Application No. 41738/10, 13 December 2016) ('Paposhvili v Belgium') (violation). See also Goodwin-Gill and McAdam (n 170) 315; Matthew Scott, 'Natural Disasters, Climate Change and Non-Refoulement: What Scope for Resisting Expulsion under Articles 3 and 8 of the European Convention on Human Rights' (2014) 26(3) International Journal of Refugee Law 404, 413.

177 Paposhvili v Belgium (n 176) [183]. See also McAdam, Climate Change, Forced Migration (n 29) 81-82. It must be noted that persons fleeing from submerging territories will generally not be critically ill. However, sending them back to these territories could potentially result in the reduction of their life expectancies.

178 Nv United Kingdom (n 176) [42]. 
islanders suffer grave violations of their human rights due to degrading or inhuman conditions on submerging islands.

Consequently, although there is no decided case yet regarding the disappearance of island states, it is arguable that states will refrain from returning former islanders in the future because 1) there is no territory left or 2) they are obligated under the non-refoulement principle as the disappearance of island states could trigger compelling humanitarian grounds against removal. ${ }^{179}$

Although protection possibilities for stateless persons exist de lege lata, their effective human rights protection remains limited and will have to be assessed on a case-by-case basis in the future. Thus, whether stateless persons might enjoy protection under the Conventions on Statelessness will largely depend on the particular state they seek as refuge after they are displaced. The same applies to their protection under international human rights treaties such as the ICCPR and the ICESCR. The lack of diplomatic protection, however, offers serious consequences for stateless persons. The 1951 Refugee Convention will most likely not be applicable to displaced islanders from submerged territories. Hence, it seems that the current status of international law does not offer sufficient human rights protection for those stateless persons.

\section{CONCLUSION}

This paper has illustrated several legal problems with regard to statelessness resulting from disappearing island states. Most importantly, it is unclear whether the people affected may be considered 'stateless people' within the meaning of the Conventions on Statelessness and, even if they did, how far that would serve to protect their rights effectively. Legal certainty on this issue will likely become more pressing in the future. In addition, under the current international human rights regime, enforcement of the rights of both de jure as well as de facto stateless people is problematic. All of these issues are particularly pertinent to the region most likely to see an influx of people fleeing from rising sea levels. It remains to be seen how international law will deal with this global challenge in the future and whether states will find timely solutions for the protection of displaced populations.

Those problems would, of course, only arise if those displaced islanders were considered stateless. With regard to the general problem of statelessness, scholars have pointed out that it is important "to stop statelessness "at source" by strengthening the principles governing acquisition of nationality'. 180 This might also be applicable in the case of disappearing island states. While there is no general right to a nationality that applies to every person by virtue of being human, it is worth considering adopting new rules de lege ferenda, which might help to naturalise stateless persons in the context of disappearing island states. Already existing instruments adopting such rules in the context of state succession might serve as guidance. However, while it seems easy to confer the obligation to grant nationality on the successor state, it will likely be an extremely difficult task to convince governments to confer their nationalities to stateless persons of

179 Cf Goodwin-Gill and McAdam (n 171) 289; Cf McAdam, 'Climate Change Displacement and International Law' (n 168).

180 Foster and Lambert (n 22) 571-72. 
disappearing island states. Ultimately, which state has the obligation to confer its nationality on those stateless displaced islanders?

In general, a first step towards more effective protection of stateless persons would be the ratification of both Conventions on Statelessness by future hosts of displaced islanders. It would also prove very helpful to have the ILA Sea Level Rise Committee elaborate further on the challenges surrounding statehood, nationality and human rights in the context of disappearing island states. That task will be essential in light of the consequences for displaced populations due to territories that are disappearing. 